\title{
The use of ustekinumab in patients with psoriasis and coexisting renal or hepatic dysfunction - a report of two cases
}

\section{Zastosowanie ustekinumabu u pacjentów z łuszczycą zwykłą oraz współistniejącymi zaburzeniami czynności nerek lub wątroby - opis dwóch przypadków}

\author{
Hubert Arasiewicz, Ligia Brzezińska-Wcisło, Bartosz Miziołek, Anna Michalska-Bańkowska
}

Department of Dermatology, Medical University of Silesia, Katowice, Poland

Przegl Dermatol 2014, 101, 405-408

DOI: $|0.5|$ |4/dr.20|4.46072

\section{KEY WORDS:}

ustekinumab, psoriasis, renal failure, toxic hepatitis.

SŁOWA KLUCZOWE:

ustekinumab, łuszczyca, niewydolność nerek, toksyczne uszkodzenie wątroby.
ADDRESS FOR CORRESPONDENCE: Hubert Arasiewicz

Department of Dermatology

Medical University of Silesia

20/24 Francuska St

40-027 Katowice, Poland

e-mail:

hubert.arasiewicz@gmail.com

\begin{abstract}
Introduction. Psoriasis is a chronic inflammatory disorder with a genetic and environmental background. The use of biological agents in cases of refractory psoriasis and psoriatic arthritis proved to be a breakthrough due to their effectiveness and safety profile. An indication for biological agents, apart from the lack of therapeutic effect, is the occurrence of side effects during conventional treatment. Commonly used systemic therapies are associated with occurrence of a cumulative toxic effect that requires modification or even discontinuation of treatment. According to the literature, ustekinumab is generally safe and well tolerated, but there is no comprehensive information about its possible adverse effects on the liver or kidneys.

Objective. Presentation of two clinical cases of patients with psoriasis and renal or hepatic impairment treated with ustekinumab.

Case reports. Case 1 concerns a 62-year-old woman with generalized psoriasis and chronic renal insufficiency in stage III, while case 2 concerns a 61-year-old man with generalized psoriasis and concomitant toxic liver damage. Both patients were successfully treated with ustekinumab.

Conclusions. Presented cases and literature data indicate that ustekinum$\mathrm{ab}$ is relatively safe in patients with psoriasis and concomitant renal or liver malfunction.

\section{STRESZCZENIE}

Wprowadzenie. Łuszczyca jest przewlekłym schorzeniem zapalnym o podłożu genetycznym i środowiskowym. Zastosowanie leków biologicznych w przypadkach opornej na leczenie łuszczycy zwykłej oraz łuszczycowego zapalenia stawów okazało się przełomową alternatywą ze względu na ich skuteczność oraz bezpieczeństwo. Częstym wskazaniem do zastosowania leków biologicznych, oprócz braku efektu terapeutycznego, jest wystąpienie działań niepożądanych $\mathrm{w}$ trakcie konwencjonalnej terapii łuszczycy zwykłej. Stosowane powszechnie leczenie systemowe wiąże się z występowaniem toksycznego efektu kumulatywnego, wymagającego modyfikacji lub zaprzestania leczenia. W piśmiennictwie nie spotkano wzmianek na temat ewentualnego toksycznego działania ustekinumabu na wątrobę lub nerki.
\end{abstract}


Cel pracy. Przedstawienie dwóch przypadków klinicznych zastosowania ustekinumabu u pacjentów z łuszczycą zwykłą oraz współistniejącymi zaburzeniami czynności nerek lub wątroby.

Opis przypadków. Przypadek 1. dotyczy 62-letniej kobiety z uogólnioną łuszczycą zwykłą oraz współistniejącą przewlekłą niewydolnością nerek w stadium III, a przypadek 2. - 61-letniego mężczyzny z uogólnioną łuszczycą zwykłą i współistniejącym toksycznym uszkodzeniem wątroby. W obu przypadkach skuteczne okazało się leczenie ustekinumabem.

Wnioski. Przedstawione przypadki oraz dane z piśmiennictwa wskazują na względne bezpieczeństwo stosowania ustekinumabu u pacjentów z łuszczycą zwykłą i współistniejącymi zaburzeniami czynności nerek i wątroby.

\section{INTRODUCTION}

Psoriasis is a chronic inflammatory disorder with a genetic and environmental background affecting approximately $2 \%$ of the general population. Even the limited forms of the disease (hands, feet, scalp, genital area) have a negative impact on the patient's quality of life which prompts development of depression and suicidal tendencies. Because of skin lesions, psoriatic patients may experience social exclusion. Furthermore, patients with psoriasis have an increased risk of sudden cardiac death and live on average 5 years shorter than the general population. This phenomenon is not fully explained by the cumulative effect of chronic inflammation, stress and end-organ toxicities of drugs. Approximately 20\% of patients present skin lesions evaluated by body surface area (BSA) as moderate $(\geq 5 \%$ BSA $<10 \%)$ or severe (BSA $>10 \%$ ), which are an indication for systemic therapy. Currently in such cases the treatment of choice encompasses photochemotherapy, methotrexate, cyclosporine and acitretin. Each of these therapies is associated with a certain risk of adverse effects because of the long-term nature of the disease. Renal or liver impairment is a contraindication to conventional therapy with methotrexate, cyclosporine or psoralens, which significantly reduces the number of therapeutic approaches. The new biologic therapies selectively target key cytokines and receptor molecules in the $\mathrm{T}$ cell mediated inflammatory process. They provide a valuable alternative because of the effectiveness and the high safety profile. There are cases with hepatitis $C$ and chronic renal failure treated with ustekinumab with a good clinical response. However, due to the lack of available pharmacokinetic data about ustekinumab in this group of patients, we should give them special attention. In our cases, we have used ustekinumab, which is a fully human monoclonal antibody against interleukin
(IL)-12/23. We included patients with psoriasis with a lack of therapeutic effects or with contraindications to conventional therapy. Moreover, they met the inclusion criteria [Psoriasis Area Severity Index (PASI) $>18$, BSA $>10$ with substantial quality of life impairment - DLQ $\geq 10$ ]. Despite a high safety profile well documented in the literature, the application of the biological drug should be preceded by numerous laboratory tests that are intended to exclude foci of infection $[1,2]$.

\section{OBJECTIVE}

Presentation of two patients with psoriasis and concomitant renal or hepatic impairment treated with biological agents.

\section{CASE REPORTS}

\section{Case I}

A 61-year-old female patient had been followed up with a diagnosis of psoriasis for more than 20 years. Since the beginning of the disease, its course was complicated by significant severity of skin lesions requiring systemic therapy. Despite the treatment, only short periods of remission were observed. In addition, there was a tendency to erythroderma during the attempts of drug discontinuation. Moreover, the patient was sensitive to UV light, which excluded photo - or photochemotherapy. During many years of treatment, methotrexate and acitretin were used, but there appeared side effects - an increase in liver enzymes and lipid parameters - that were a contraindication for continuation of the therapy. Cyclosporin was also used, but due to the occurrence of a side effect in the form of chronic renal failure we stopped the therapy. As there was a failure of conventional methods, due to the lack of satisfactory clinical improve- 
A

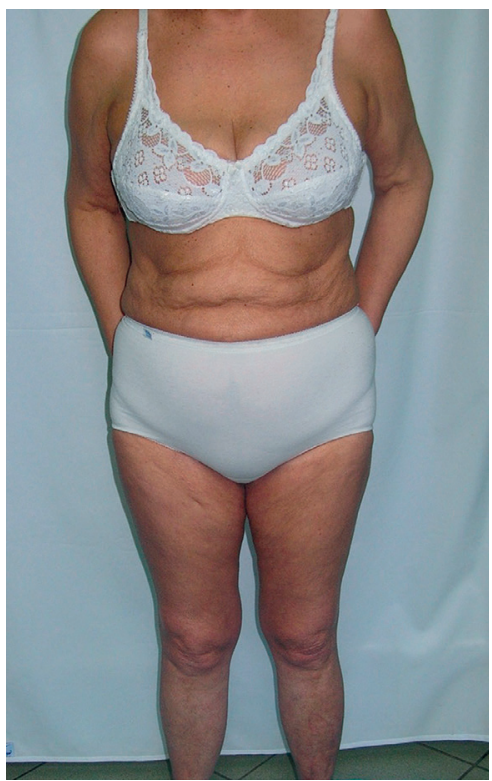

B

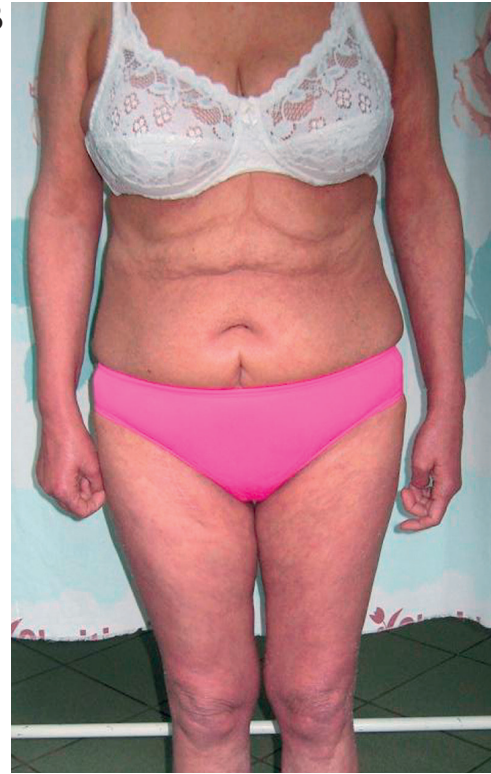

Figure I. A - Lesions on the trunk before starting treatment with ustekinumab. B - Complete clearance after treatment with ustekinumab Rycina I. A - Zmiany skórne w obrębie tułowia przed rozpoczęciem leczenia ustekinumabem. B - Remisja zmian skórnych po leczeniu ustekinumabem

ment, contraindications for their long-term use and the severity of skin lesions, the patient was incorporated in a biological treatment program. She was consulted by a nephrologist to rule out any contraindication to biological therapy, and she has subsequently been followed by the Outpatient Nephrology Clinic. In August 2013, she was qualified for ustekinumab at a standard dose of $45 \mathrm{mg}$ subcutaneously initially and once again 4 weeks later, followed by $45 \mathrm{mg}$ once every 12 weeks. The patient showed a significant improvement of PASI score with a single exacerbation incident due to infection of the upper respiratory tract which regressed without complications. There were no adverse effects and no differences in laboratory tests compared to baseline. The patient is followed by our Outpatient Dermatology Clinic with satisfactory clinical improvement of skin lesions (Figure 1).
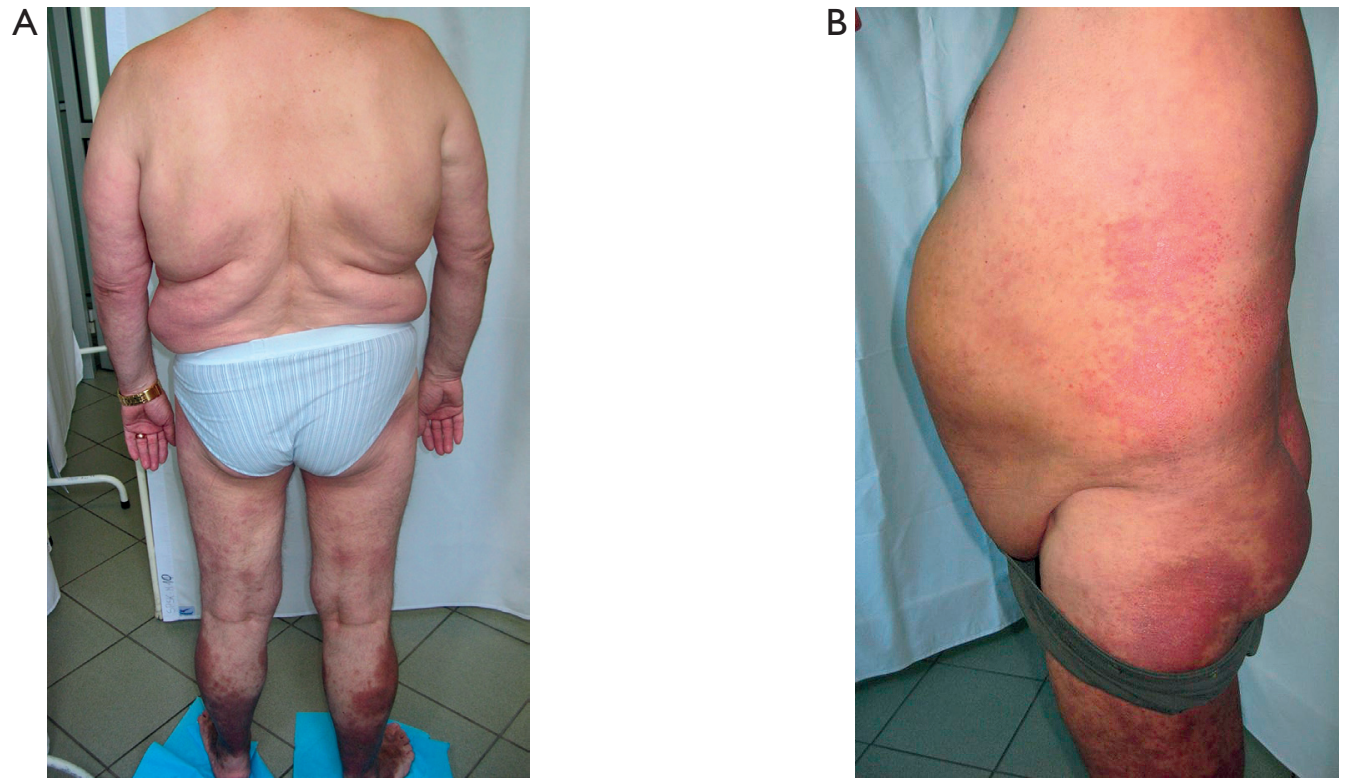

Figure 2. A - Lesions on the trunk before starting treatment with ustekinumab. B - Complete clearance after treatment with ustekinumab Rycina 2. A - Zmiany skórne w obrębie tułowia przed rozpoczęciem leczenia ustekinumabem. B - Remisja zmian skórnych po leczeniu ustekinumabem 


\section{Case 2}

A 60-year-old male patient had been followed up with a diagnosis of psoriasis for more than 30 years. The patient was repeatedly hospitalized and treated with conventional systemic therapies such as methotrexate, cyclosporine, acitretin, and phototherapy, without satisfactory remission of skin lesions. In March 2012, during the administration of methotrexate, some side effects in the form of enlargement of the liver with increased activity of liver enzymes was noticed. That was the reason for discontinuation of the therapy. The patient was admitted to the Hepatology Clinic, where drug-induced hepatotoxicity was diagnosed. In addition, the patient met the criteria for metabolic syndrome. Due to contraindications to retinoids and psoralens, the patient was treated with UVB 311 without a significant improvement (Figure $2 \mathrm{~A}$ ). Because of the severity of skin lesions and contraindications to conventional therapy, the patient was proposed for a biological treatment program. He was consulted by a hepatologist who excluded contraindications to biological agents. Liver damage was drug induced and had no viral (HBs antigen, anti-HCV antibodies) or autoimmune origin. In August 2013, after the screening tests, the first dose of $90 \mathrm{mg}$ of ustekinumab (body weight $>100$ $\mathrm{kg}$ ) was administered subcutaneously. The patient did not complain of any side effects during treatment and showed a significant improvement of PASI, BSA and Dermatology Life Quality Index (DLQI) scores. There were no evident variations in blood tests compared to the baseline. The patient is followed at our Outpatient Dermatology Clinic with satisfactory clinical improvement (Figure $2 \mathrm{~B}$ ).

\section{DISCUSSION}

Psoriasis is a chronic systemic disease with a tendency to exacerbation under the influence of environmental factors and endogenous foci of infection. Increased incidence of metabolic syndrome consisting of hypertension, abdominal obesity, type 2 diabetes and dyslipidemia is also observed. Due to the chronic course of psoriasis and the fact that approximately $20 \%$ of patients need systemic therapy, the disease is a big therapeutic and economical challenge. Despite the introduction of biological drugs, which are according to the studies generally safe and well tolerated, photochemotherapy, methotrexate, cyclosporine and acitretin have still remained the basis of treatment. Each of these agents is associated with a certain risk of side effects which cannot be fully avoided by detailed examinations. Therefore, the systemic therapy is always adjusted depending on the actual patient's needs. Side effects of conventional therapies, such as those observed in our patients, include liver toxicity after methotrexate and chronic renal failure after cyclosporin. Other common side effects include teratogenicity, dyslipidemias and dryness of mucous membranes observed during treatment with retinoids or hypertension and carcinogenicity in patients treated with cyclosporin. The lack of satisfactory results after the conventional methods of treatment or contraindications to their use allows one to consider biological therapy. So far, in the literature there are not many case reports considering the use of biological therapy with pre-existing liver or kidney impairment. Important contraindications for biological agents are hepatitis $\mathrm{B}$ and autoimmune diseases. In both of our patients, remission of skin lesions was achieved without affecting the coexisting disorders of liver or kidneys. The presented cases and literature analysis suggest that the biological agents may be relatively safe in patients with psoriasis or psoriatic arthritis and concomitant hepatic and renal malfunction [3-7].

\section{References}

1. Menter A., Korman N., Elmets C., Feldman S., Gelfand J., Gordon K., et al.: Guidelines of care for the management of psoriasis and psoriatic arthritis: Section 6. Guidelines of care for the treatment of psoriasis and psoriatic arthritis: case-based presentations and evidence-based conclusions. J Am Acad Dermatol 2011, 65, 137-174.

2. Chiu H., Chen C., Wu M., Cheng Y., Tsai T.: The safety profile of ustekinumab in the treatment of patients with psoriasis and concurrent hepatitis B or C. Br J Dermatol 2013, 169, 1295-1303.

3. Kauffman C., Aria N., Toichi E., McCormick T., Cooper K., Gottlieb A., et al.: A phase I study evaluating the safety, pharmacokinetics, and clinical response of a human IL-12 p40 antibody in subjects with plaque psoriasis. J Invest Dermatol 2004, 123, 1037-1044.

4. Bustos B., Sanchez R., Martínez V., Carazo J.: Efficacy and safety of ustekinumab in a patient with chronic renal failure on hemodialysis. Int J Dermatol 2014, 53, 299-301.

5. Gottlieb A., Narang K.: Ustekinumab in the treatment of psoriatic arthritis: latest findings and clinical potential. Ther Adv Musculoskelt Dis 2013, 5, 277-285.

6. Papp K., Griffiths C., Gordon K., Lebwohl M., Szapary P., Wasfi Y., et al.: Long-term safety of ustekinumab in patients with moderate-to-severe psoriasis: final results from 5 years of follow-up. Br J Dermatol 2013, 168, 844-854.

7. McInnes I., Kavanaugh A., Gottlieb A., Puig L., Rahman P., Ritchlin C., et al.: Efficacy and safety of ustekinumab in patients with active psoriatic arthritis: 1 year results of the phase 3, multicentre, double-blind, placebo-controlled PSUMMIT 1 trial. Lancet 2013, 382, 780-789. 